\title{
Andrew MASSEY (Ed.), A Research Agenda for Public Administration
}

Petra Svensson

\section{(2) OpenEdition \\ Journals}

Electronic version

URL: https://journals.openedition.org/irpp/1741

DOI: 10.4000/irpp.1741

ISSN: 2706-6274

Publisher

International Public Policy Association

\section{Printed version}

Date of publication: 15 March 2021

ISSN: 2679-3873

Electronic reference

Petra Svensson, "Andrew MASSEY (Ed.), A Research Agenda for Public Administration", International Review of Public Policy [Online], 3:1 | 2021, Online since 15 March 2021, connection on 17 June 2021. URL: http://journals.openedition.org/irpp/1741 ; DOI: https://doi.org/10.4000/irpp.1741

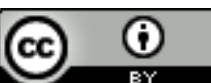

International Review of Public Policy is licensed under a Creative Commons Attribution 4.0 International. 


\section{Book Review}

\section{Andrew MASSEY (Ed.), \\ A Research Agenda for Public Administration}

\section{Petra Svensson}

Universitetslektor i statsvetenskap/Senior lecturer in Political Science

Akademin för lärande, humaniora och samhälle/School of Education, Humanities and Social Sciences Högskolan i Halmstad/Halmstad University, Sweden

\section{A Research Agenda for Public Administration Andrew Massey}

Massey, Andrew (Ed.), Cheltenham (UK) \& Northampton (USA):Edward Elgar Publishing, 2019, 241 p., ISBN 9781788117241. Hardback: £100.00, \$150; Paperback: £24.95; £31.96; eBook: £19.96, \$31.96 2019 
The academic field of public administration is characterized by the long-standing debate on what constitutes the field in terms of academic discipline. Which theories, methods, designs and topics define the field, and how are these distinct from other research fields? The question can be daunting, especially for new scholars and students, and therefore a compiled research agenda, such as this book, is welcome indeed. The anthology is a part of the series Elgar Research Agendas, targeting research agendas in various fields. In the introductory chapter, Andrew Massey argues that the departure points of A Research Agenda for Public Administration are the diverse character of public administration as research field, and its unifying objects of study: the state, public sector and public realm, rather than its aims, methods and theories. This statement is a necessary one for a book on such a diverse research agenda.

The chapters may be divided into two groups. The former covers the more epistemological characteristics of public administration as a field, such as reflections on the development of the public administration research field (Massey and Drechsler), the interpretative turn in public administration (Rhodes), and the relationship between the academic field and practitioners (Pollitt, Walker, Dunlop and Steen, Brandsen \& Verschuere). The latter covers specific topics in the field, such as public administration in East Asia (Kim and Lan), digital governance (Evans, Dunleavy, McGregor \& Halupka), governance in small states (Randmaa-Liiv \& Sarapuu), comparative public administration (Kuhlmann), regulation and corruption (Dunlop \& Radaelli), and public service motivation (Brewer). Each chapter covers the development of the topic at hand and ends with some tensions constituting potential future research paths. The chapters offer consolidated, useful overviews. It is also nice to see a compiled work like this, where the authors represent academic institutions across the globe.

Readers more interested in the frontier of research will appreciate the second group of chapters because of their smooth introductions to a range of topics combined with clarification of the most pressing and relevant research questions. Several chapters stress the necessity to consider the impact of geography, culture and local context. The first group of chapters holds distinct value, too, since the development of the public administration field, which takes place in close relation to its subject of study - the state, the public sector and the public realm - is in constant need of revision and reflection. The book takes a firm stand in stating that public administration is specific in its combination of scientific study and its capacity to contribute to improved public service and governance. Massey writes in the introduction: "In order to embrace this appeal for a responsive PA that addresses the intractable problems of society and seek to do so within a framework of good governance, or at the very least to do no harm (to paraphrase the Hippocratic Oath), future research must be innovative, challenging and above all, it must be brave. It needs to speak truth unto power and meet head on the wicked issues of the day, not the least of which is malfeasance by those who have assumed high office." (p. 3).

In the final chapter, Drechsler discusses how the pressure to publish in specific journals according to pre-determined standards risks making the public administration scholar redundant, since, as he puts it provocatively, a computer could create these algorithm-articles better than the public administration scholar. He raises a serious warning flag. Drechsler also stresses that there are many ways of conducting public administration research. He argues that there is a bias toward European philosophical tradition when understanding the foundation of public administration, at the expense of, for example, Buddhist and Confucian tradition. Although the statement of Western dominance is not any sense a new one, I find the connection to philosophical traditions very interesting and inspiring. There must be room for more texts of this kind. 
Overall, the volume rightly speaks to its readers as a research agenda for public administration, but not the one and only one. Other topics could definitely have been included, and the book is also somewhat unbalanced between the chapters discussing the characteristics of public administration as a field and those focusing on specific topics. That said, the book makes for a rewarding read on both. It has distinct strengths in the chapters' presentations of current tensions and topics of investigation. These are generally broad enough to give overall directions without becoming vague, and still specific enough to serve as a direct inspiration for further studies, both for students and scholars. It also has a clear strength in its firm stance on the importance of the academic-practitioner relationship and it will be useful to anyone interested in the state of the art of public administration as a research field. Specifically, it is an original 'framing' of a somewhat messy research. Graduate students would find inspiration in this book, as well as senior researchers interested in the topics and/or grappling with the relationship between academic public administration and the practice of governance and public management. 